\title{
DOES CORPORATE SOCIAL RESPONSIBILITY REDUCE INFORMATION ASYMMETRY?: EMPIRICAL EVIDENCE FROM PAKISTAN
}

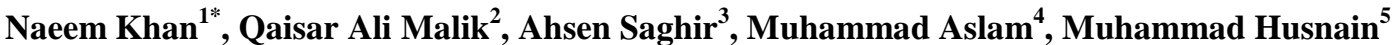

${ }^{1 *}, 3$ Ph.D., Scholar, Foundation University Islamabad, Rawalpindi Campus, Pakistan; ${ }^{2}$ Associate Professor/ Head of department, Foundation University Islamabad, Rawalpindi Campus, Pakistan; ${ }^{4}$ Lecturer, Lahore School of Accountancy \& Finance, University of Lahore, Pakistan; ${ }^{5}$ Assistant Professor, Department of Business Administration, University of Sahiwal, Sahiwal, Pakistan.

Email: "naeemkkhan87@gmail.com

Article History: Received on $5^{\text {th }}$ June 2021, Revised on $12^{\text {th }}$ June 2021, Published on $14^{\text {th }}$ June 2021

\section{Abstract}

Purpose: The work empirically investigates the effect of corporate social responsibility (CSR) on information asymmetry (IA).

Methodology: For analysis, the study uses annual data ranging from 2007 to 2017, collected from the published reports of companies registered at the Pakistani equity market comprising the non-financial sector. An unbalanced panel of 257 companies with 2383 observations is analyzed using the generalized methods of moment (GMM) technique.

Main findings: In line with stakeholder's theory, results disclose a negative association between the variable of CSR and IA. It suggests that investing in CSR-related activities will reduce the asymmetry of information among managers and shareholders.

Application of the study: Findings of the study uncover the benefits of CSR in relation to IA that must be considered while formulating any strategy both at the governmental and corporate level. Government should facilitate corporations that engage in CSR work while firms must include CSR in their policy-making as it can significantly reduce information asymmetry.

Novelty/ originality of the study: This study provides a deep analysis in the form of behavioural association and the effect of CSR practices on information asymmetry in the context of the Pakistani non-financial sector. The study endorses the concept of CSR practices for the reduction of information asymmetry in Pakistani firms.

Keywords: CSR, Information Asymmetry, Non-financial Sector, PSX, GMM.

\section{INTRODUCTION}

CSR is a renowned topic in the literature of finance, management, and economics (Sheikh, 2019). A major portion of research explores the relation of CSR with the performance of the firm and its value (Lee et al., 2020; Utz, 2018). The benefit of investing in CSR activities towards business and community are still debatable. There are several reasons for this. For instance, academics and practitioners have very different conceptions of CSR, resulting in a wide variety of research topics and results (Garriga \& Melé, 2004). Second, the insights into the nature of CSR are still not clear (Choongo, 2017). Third, CSR can benefit companies in terms of risk reduction and cost, and it also benefits to take a competitive benefit (Gangi et al., 2018). It results in their commitment to CSR, and businesses will become more appealing to investors (Carroll \& Shabana, 2010; Nguyen et al., 2020). Thus, increasing costs through CSR activities will boost a company's image while sacrificing short-term financial results. However, competitive advantages can be gained in the long run (Kiran et al., 2015). El Ghoul et al. (2011) finds an inverse relation of CSR score with equity cost, using a variety of methods to measure firms' ex-ante equity cost. According to Aupperle et al. (1985), implementing CSR would result in competitive disadvantages due to the additional costs involved. The main point is that there is a negative association in social and financial efficiency because of the additional costs incurred to enhance social or environmental performance, which does not increase shareholder value (Choongo, 2017). CSR is a multidimensional and complex concept (Harjoto \& Jo, 2011). CSR refers to serving people in such a way to go beyond the legal requirement (Abbas et al., 2019). Overall, CSR is to utilize the firm's resources in such a way as to foster the sustainability of firms and to promote information transparency and accountability (Cui et al., 2018). However, researchers have written various papers on the relation of CSR with key financial measures to understand the effect and relational significance of CSR (Agyemang \& Ansong, 2017; Al-Hadi et al., 2019; Andi et al., 2019; Blasi et al., 2018; El Ghoul et al., 2011; Galbreath \& Shum, 2012; Kiran et al., 2015; Samet \& Jarboui, 2017; Skufina et al., 2019). Though, literature discloses that a consensus could not be established on how CSR affects firm performance and other related variables (Sheikh, 2019; Van Ha, 2018; Yang et al., 2019).

In recent times, information asymmetry remains one of the most debated and favourite topics of shareholders as a company that offers more information disclosures must be able to understand and fulfill the need of stakeholders (Bergh et al., 2019; Martínez-Ferrero et al., 2018; Utama, 2019). The shareholder will be pleased if a company is providing detailed facts and figures. Modigliani and Miller (1963) documents that investors and company managers have similar information related to the future of firms. However, in practice, managers have more insight than external stakeholders (Alamgir \& Nasir Uddin, 2017). Easley and O'hara (2004) formulate a method of IA and finds that investors who 
demand more premium are uninformed investors. Information asymmetry also affects the efficiency of the capital market at a time when some investors have more information on the company's internal affairs and its share pricing (Chaleeda et al., 2019; Drobetz et al., 2010). The information system is another vital factor that determines equity risk, the equity cost, and the firm performance (Wang et al., 2013). High equity cost and a firm's low liquidity are the results of a volatile environment within the company, and such an environment stimulates dealing friction through an adverse choice (Van Ha, 2018).

The goal of current research is to empirically discover and document the relational behaviour and CSR effect on information asymmetry. The linkages of CSR-firm performance have been investigated extensively, the association of CSR practices with information asymmetry is relatively less explored, especially in developing countries (Bergh et al., 2019; Buallay et al., 2020; Choongo, 2017; Ishtiaq et al., 2017; John et al., 2019; Pisani et al., 2017; Saeidi et al., 2015). The association of CSR-IA is important to many not just because of the modern development of the IA concept but its inclusion in the field of economics, accounting, finance, and management. This work reduces the study gap in the literature through investigating both relational behaviour and CSR effect on IA using the non-financial sector data sets comprising annualized values of companies registered Pakistani capital market. As per the literature reviewed concerning developing countries and the author's understanding, no such work on the linkage of CSR and information asymmetry has previously been undertaken in Pakistan.

\section{The objective of this study is to explore the impact of corporate social responsibility on information asymmetry in the context of Pakistan.}

The remaining article is as under: The second portion reviews the related literature. The third portion explains the methodology of the study, including sample, data, and tools used to analyze the data. The fourth portion reports explanation of the results followed by the findings of the study. The fifth portion concludes this study and provides future research directions.

\section{LITERATURE REVIEW}

In the last few years, researchers found many benefits of CSR engagement which includes: CSR improves communication with stockholders (Fieseler, 2011); increase in firm value (Blazovich \& Smith, 2011; Harjoto \& Jo, 2011); reduction in equity cost (Dhaliwal et al., 2012); effective corporate governance (Blazovich \& Smith, 2011); better communication (Dhaliwal et al., 2012); enhances creditworthiness (Attig et al., 2013); appreciation, satisfactory comments and better forecast by analysts (Dhaliwal et al., 2012). Prior research suggests that CSR practices improve a company's brand image (Albinger \& Freeman, 2000; Turban \& Greening, 1997), which is particularly significant since such companies are frequent stock market participants.

Firms with more CSR activities are linked to a sound information atmosphere in order to maintain their reputation (Cherian et al., 2019; Rettab \& Mellahi, 2019). Furthermore, it is critical for businesses to establish and keep a positive reputation, particularly for those that need more intense supervision (Su \& Swanson, 2019). Accordingly, reputation can help in reducing information asymmetry (Diamond, 1991; Sufi, 2007). Firms encounter relatively higher risk that spends more on monitoring (Dhaliwal et al., 2011; Halov \& Heider, 2011).

Literature informs that there is no consensus on CSR and IA association, and it is presumed that the link between CSR and IA is based on stakeholder's theory (Nguyen et al., 2019). There are many reasons that CSR reports are more valuable to the participants that are outside the organizations (Baron et al., 2011). Diamond and Verrecchia (1991), Healy and Palepu (2001), and Kim et al. (2012) report that CSR disclosure minimizes the asymmetry of information. CSR engagement can minimize information asymmetry if managers use it as a signalling network to improve cooperation with shareholders and overcome their disputes (Zhang et al., 2019). This relationship is known as the information asymmetry-reduction relationship (Martínez-Ferrero et al., 2018).

The issue of information asymmetry arises when organizations keep information confidential and do not let others access it (Khan et al., 2016; Saputri \& Asrori, 2019). They purposefully prevent others from accessing information as it can help stakeholders make better corporate decisions. Researchers believe that corporate discourse can help for reducing information asymmetry, which in return can improve the liquidity of a firm and reduction in equity cost (Diamond \& Verrecchia, 1991; Zhao \& Xiao, 2019). Any information, whether positive or negative, is equally important to stakeholders for decision-making.

Through an empirical investigation, Cui et al. (2018) report a negative linkage between CSR and IA relationships in risky firms. Further, reputational risk mediates the said relation. Van Ha (2018) examines the association of CSR and IA through a fixed-effects panel estimator for Australian publicly traded companies from 2004 to 2014 for a period of 10 years, results report a negatively association between CSR and IA. Despite growing scholarly interest in the implications of CSR activates, there is little experiential proof to conclude the relationship between CSR and IA. 


\section{METHODOLOGY}

\section{Data and sample}

The data of current research consists of non-financial companies registered at PSX. Financial companies are not part of the sample as they follow different reporting standards. Data of ten years ranging from 2007 to 2017 is collected from published annual reports issued by companies. Final data of 257 companies based on an unbalanced panel of 2383 observations is considered. For data analysis, the generalized methods of moment (GMM) technique is utilized in Eviews 9 software.

\section{Variables' measurement}

\section{Corporate Social Responsibility (CSR)}

The literature reports multiple proxies for the measurement of CSR. The study uses the 'CSR monetary spending ratio' for the measurement of CSR. Data relating to the spending on donations, employee's welfare, and R\&D is collected from company statements. The firm's overall CSR expenses are then estimated by combining all values of the above three heads. Following Ehsan and Kaleem (2012) and Pyo and Lee (2013), the 'monetary spending ratio of a firm' is estimated by dividing the sum of these three heads by the 'earnings after tax'.

\section{Information Asymmetry (IA)}

Insiders' superior knowledge of future success captures asymmetric details, that are estimated using a dummy variable. We use the ratio of 'net income including extraordinary elements' divided through 'assets' book value'. If the resulting value is greater than one compared to its corresponding value, we will insert 1; otherwise, 0 as used by Ataullah et al. (2014) and Piotroski and Roulstone (2005).

\section{Control Variables}

To avoid omitted variable bias, it is critical to monitor the variables that can affect insider trading (Davidson \& MacKinnon, 2004). Since debt holders are likely to track highly leveraged companies respectively, leverage is considered the first control variable of the study so that the information asymmetries may get reduced ( $\underline{\text { Harris \& Raviv, }}$ 1991). For leverage, the ratio of debt to equity is utilized. Since investors respond more readily due to insider trading to small companies accordingly, according to the work of Cui et al. (2018), the study uses firm size as the second control variable, estimated through the 'natural log of a company's total resources'. As per the study of Mashayekhi and Bazaz (2008), this study uses a third control variable of firm age, estimated through a natural log of years a company's common stock remains in the trade. In line with Cui et al. (2018), Lang et al. (1991), free cash flow is the fourth proxy of this study which is estimated through cash received from the main operation of the company less preferred and common stock dividends multiplied with the total asset of a firm.

Below equation-1 shows the model of the study:

$$
I A_{i, t}=\beta_{0}+\beta_{1} \times C S R_{i, t}+\beta_{2} \times S I Z E_{i, t}+\beta_{3} \times A G E_{i, t}+\beta_{4} \times L E V_{i, t}+\beta_{5} \times F C F_{i, t}+\varepsilon_{i, t}-(\mathrm{Eq}-1)
$$

\section{Results and empirical findings}

\section{Results of descriptive Statistics}

Table 1 presents descriptive statistics using all variables. These statistics are estimated to see any possible discrepancy and to get a general understanding of the data.

Results reveal that all the values are within acceptable limits, and no discrepancy is found in the data. For IA the mean is 0.481, standard deviation (SD) of 0.50, whereas the mean CSR is 0.014, with a standard deviation (SD) of 0.033 . The total observation of the study is 2383 . For the sake of brevity, the detailed explanation of descriptive statistics is avoided.

Table 1: Descriptive stats

\begin{tabular}{lllllll}
\hline & Mean & Median & Max & Min & SD & Obs. \\
\hline IA & 0.481 & 0.000 & 1.000 & 0.000 & 0.500 & 2383 \\
\hline CSR & 0.014 & 0.005 & 0.268 & -0.086 & 0.033 & 2383 \\
\hline SIZE & 15.265 & 15.102 & 19.344 & 11.707 & 1.469 & 2383 \\
\hline AGE & 35.572 & 32.000 & 95.000 & 1.000 & 16.021 & 2383 \\
\hline LEV & 0.167 & 0.147 & 0.546 & 0.003 & 0.124 & 2383 \\
\hline FCF & 0.026 & 0.021 & 0.226 & -0.156 & 0.055 & 2383 \\
\hline
\end{tabular}

\section{Results of correlations Coefficients}

Table 2 presents the results of correlation analysis. This association of variables can be either positive, negative, or zero. Correlation analysis discloses that data is free of multicollinearity problems among the variables used. 
Statistics of correlation reports a negative sign for CSR and IA association which means that with an increase in CSR, the IA will be reduced. For control variables, SIZE and LEV are negatively associated with IA, while the AGE and FCF are positively associated with IA.

Table 2: Correlation coefficients

\begin{tabular}{lllllll}
\hline & CSR & IA & SIZE & AGE & LEV & FCF \\
\hline CSR & 1.000 & & & & & \\
\hline IA & -0.019 & 1.000 & & & & \\
\hline SIZE & -0.063 & -0.010 & 1.000 & & & \\
\hline AGE & 0.013 & 0.063 & 0.080 & 1.000 & & \\
\hline LEV & -0.023 & -0.058 & 0.060 & -0.170 & 1.000 & \\
\hline FCF & 0.054 & 0.072 & 0.116 & 0.046 & -0.210 & 1.000 \\
\hline
\end{tabular}

\section{Results of Regression analysis}

Table 3 presents the ordinary least square (OLS) technique, fixed effect, random effect, and GMM and the coefficients, $\mathrm{t}$-values, and p-values for all models involved.

Results of the OLS model suggest the CSR has significant and negative effects on IA. The effect of firm size on information asymmetry (IA) is negative and significant. The impact of the age of the firm on IA is positive and significant. Leverage has an insignificant effect on IA. The free-cash-flow affects IA positively. The value of adjusted $\mathrm{R}^{2}$ is 0.1080 , which means independent variables causes 10.80 percent variance in the dependent variable. The probability of f-stats is significant, indicating that the model structurally sounds fit for the data. For both models, fixed and random effect, CSR effects negatively to IA. The control variables of firm age and free-cash-flow have a positive effect on IA, whereas the size of the firm and leverage have a negative effect on IA. The value of adjusted $\mathrm{R}^{2}$ for the fixed effect model is 0.137 , which means the independent variable causes 13.70 percent variance in the dependent variable probability of f-statistics is significant, indicating fitness of the model for the data.

For the random effect model, the control variables firm age and free cash flows have a significant positive impact on information asymmetry, while the size of the firm has a negative effect on information asymmetry. The effect of leverage on IA is, however, insignificant. The value of adjusted $\mathrm{R}^{2}$ for the random effect model is 0.113 , which means the independent variable causes 11.30 percent variance in the dependent variable. The probability of F-statistics is significant, which designates a perfect fit of data to the model.

The results of the GMM model also report similar findings. Analysis shows that CSR affects significantly negatively IA. The stats of adjusted $\mathrm{R}^{2}$ show that the independent variable causes at least 20 percent variance. The probability of Jstatistics is also insignificant.

Table 3: Effect of CSR on IA

\begin{tabular}{|c|c|c|c|c|c|c|c|c|c|c|c|c|}
\hline \multicolumn{3}{|c|}{ OLS } & \multicolumn{4}{|c|}{ Fixed Effect } & \multicolumn{3}{|c|}{ Random Effect } & \multicolumn{3}{|l|}{ GMM } \\
\hline Variables & Coef & t stats & Prob & Coef & t stats & Prob & Coef & t stats & Prob & Coef & t stats & Prob \\
\hline CSR & -0.051 & -2.661 & 0.008 & -0.257 & -1.987 & 0.047 & -0.051 & -2.601 & 0.009 & -0.025 & -3.076 & 0.002 \\
\hline SIZE & -0.586 & -3.033 & 0.002 & -0.413 & -3.390 & 0.001 & -0.774 & -1.909 & 0.056 & -0.413 & -3.314 & 0.001 \\
\hline AGE & 0.051 & 2.926 & 0.004 & 0.157 & 2.335 & 0.020 & 0.051 & 2.779 & 0.006 & 0.030 & 1.374 & 0.170 \\
\hline LEV & -0.134 & -1.562 & 0.119 & -0.166 & -1.951 & 0.051 & -0.134 & -1.527 & 0.127 & -0.250 & -1.868 & 0.062 \\
\hline FCF & 0.586 & 2.553 & 0.011 & 0.901 & 3.773 & 0.000 & 0.586 & 2.965 & 0.003 & -0.511 & -1.087 & 0.277 \\
\hline Adj. $R^{2}$ & 0.108 & & & 0.137 & & & 0.113 & & & 0.201 & & \\
\hline$F$-stats & 4.186 & & & 6.346 & & & 4.186 & & & & & \\
\hline$P . F$-stats & 0.000 & & & 0.000 & & & 0.000 & & & & & \\
\hline P. J-stats & & & & & & & & & & 0.884 & & \\
\hline
\end{tabular}

The results of the OLS model, fixed effect technique, random effect technique, and the GMM technique study confirms the negative impact of CSR on information asymmetry (IA). Results are in line with the studies of Cho et al. (2013), Lopatta et al. (2016), Lu and Chueh (2015), Nguyen et al. (2019), Samet and Jarboui (2017), and Cui et al. (2018) confirming a negative association between CSR and IA. The stakeholder's theory, suggests that shareholders must have their say in the decision-making of the company (Donaldson \& Preston, 1995). Prior literature also reports that CSR is associated with good reporting standards. The engagement in CSR work is positively associated with better corporate reporting (Cao et al., 2012). The CSR work motivates manages to produce good accounting reports. The theory further states that managers must make such acts that benefit not only shareholders but also stakeholders. Fulfilling the expectations of stakeholders regarding the CSR work can result in a positive image of the company. Companies with good repute may produce higher profits that is fundamentally associated with lower information asymmetry (IA). 


\section{CONCLUSION}

The association of CSR and IA is important in many ways, especially its connections to finance, economics, accounting, and management. Although researchers have duly considered the CSR and firm performance association, the linkage of CSR to IA received relatively far less attention, particularly in developing countries. This research addresses a gap in the literature by looking at relational behaviour and the effects of CSR on information asymmetry. The study investigates the relational behaviour and the impact of CSR on information asymmetry (IA) by utilizing the data comprising nonfinancial firms of PSX for ten years from 2007 to 2017. The results of the correlation statistics report a negative sign for the CSR and IA association. Findings are robust, as confirmed by relatively similar results obtained through four different statistical models suggesting that investment in CSR work will significantly reduce the asymmetry of information.

\section{IMPLICATIONS}

The study has a number of significant implications for company managers and stakeholders as well as regulators. For policymakers, the study highlights the need for legislative change to support CSR operations in Pakistan and other developing countries since it has been established that increasing CSR operation increases knowledge transparency in capital markets. This can be accomplished by providing incentives to businesses so they may duly participate in CSR work. The empirical findings also suggest that participating in CSR should be viewed as a strategic move that, in return, can reduce their financing costs by improving their information-based environment.

\section{STUDY LIMITATIONS}

The research sample is restricted to one country only. For the generalizability of findings, more developing countries should be considered in future research. And, the analysis does not incorporate the effect of structural influences on CSR activities and disclosure practices.

\section{FUTURE RESEARCH}

More research is desirable to consider the effect of CSR on IA in long-term financial setup in different countries. Future studies should also look at how ethical decision-making affects the information system in different cultures.

\section{CONTRIBUTION OF EACH AUTHOR}

Naeem Khan and Qaisar Ali Malik conceived, initiated the idea of current research. They took the lead in drafting the document with the inputs of all authors. Ahsen Saghir and Muhammad Aslam collected all related data, prepared an excel sheet for final data testing, and formatted the final document. Naeem Khan, Ahsen Saghir and Muhammad Husnain planned and performed data analyses. All authors have made a significant contribution to this research.

\section{REFERENCES}

1. Abbas, J., Mahmood, S., Ali, H., Ali Raza, M., Ali, G., Aman, J., Bano, S., \& Nurunnabi, M. (2019). The Effects of Corporate Social Responsibility Practices and Environmental Factors through a Moderating Role of Social Media Marketing on Sustainable Performance of Business Firms. Sustainability, 11(12), 3434. https://doi.org/10.3390/su11123434

2. Agyemang, O. S., \& Ansong, A. (2017). Corporate social responsibility and firm performance of Ghanaian SMEs: Mediating role of access to capital and firm reputation. Journal of Global Responsibility, 8(1), 47-62. https://doi.org/10.1108/JGR-03-2016-0007

3. Al-Hadi, A., Chatterjee, B., Yaftian, A., Taylor, G., \& Monzur Hasan, M. (2019). Corporate social responsibility performance, financial distress and firm life cycle: evidence from Australia. Accounting \& Finance, 59(2), 961-989. https://doi.org/10.1111/acfi.12277

4. Alamgir, M., \& Nasir Uddin, M. (2017). The mediating role of corporate image on the relationship between corporate social responsibility and firm performance: An empirical study. International Journal of Business and Development Studies, 9(1), 91-111.

5. Albinger, H. S., \& Freeman, S. J. (2000). Corporate social performance and attractiveness as an employer to different job seeking populations. Journal of Business Ethics, 28(3), 243-253. https://doi.org/10.1023/ A:1006289817941

6. Andi, K., Isnaeni, R., \& Widiyanti, A. (2019). The effect of corporate social performance on financial performance with firm size as a control variable. Economics \& Commerce, 7(4), 651-658. https://doi.org/10.1 8510/hssr.2019.7485

7. Ataullah, A., Davidson, I., Le, H., \& Wood, G. (2014). Corporate diversification, information asymmetry and insider trading. British Journal of Management, 25(2), 228-251. https://doi.org/10.1111/j.1467$\underline{8551.2012 .00846 . \mathrm{x}}$

8. Attig, N., El Ghoul, S., Guedhami, O., \& Suh, J. (2013). Corporate social responsibility and credit ratings. Journal of business ethics, 117(4), 679-694. https://doi.org/10.1007/s10551-013-1714-2 
9. Aupperle, K. E., Carroll, A. B., \& Hatfield, J. D. (1985). An empirical examination of the relationship between corporate social responsibility and profitability. Academy of management Journal, 28(2), 446-463. https://doi.org/10.2307/256210

10. Baron, D. P., Harjoto, M. A., \& Jo, H. (2011). The economics and politics of corporate social performance. Business and Politics, 13(2), 1-46. https://doi.org/10.2202/1469-3569.1374

11. Bergh, D. D., Ketchen Jr, D. J., Orlandi, I., Heugens, P. P., \& Boyd, B. K. (2019). Information asymmetry in management research: Past accomplishments and future opportunities. Journal of Management, 45(1), 122-158. https://doi.org/10.1177/0149206318798026

12. Blasi, S., Caporin, M., \& Fontini, F. (2018). A multidimensional analysis of the relationship between corporate social responsibility and firms' economic performance. Ecological Economics, 147, 218-229. https://doi.org/10.1016/j.ecolecon.2018.01.014

13. Blazovich, J. L., \& Smith, L. M. (2011). Ethical corporate citizenship: does it pay? In Research on professional responsibility and ethics in accounting. Emerald Group Publishing Limited. https://doi.org/10.1108/S15740765(2011)0000015008

14. Buallay, A., Kukreja, G., Aldhaen, E., Al Mubarak, M., \& Hamdan, A. M. (2020). Corporate social responsibility disclosure and firms' performance in Mediterranean countries: a stakeholders' perspective. EuroMed Journal of Business. https://doi.org/10.1108/emjb-05-2019-0066

15. Cao, Y., Myers, L. A., \& Omer, T. C. (2012). Does company reputation matter for financial reporting quality? Evidence from restatements. Contemporary Accounting Research, 29(3), 956-990. https://doi.org/10.1111/j.19 11-3846.2011.01137.x

16. Carroll, A. B., \& Shabana, K. M. (2010). The business case for corporate social responsibility: A review of concepts, research and practice. International Journal of Management Reviews, 12(1), 85-105. https://doi.org/10.1111/j.1468-2370.2009.00275.x

17. Chaleeda, M., Islam, A., Ahmad, T. S. T., \& Ghazalat, A. N. M. (2019). The effects of corporate financing decisions on firm value in Bursa Malaysia. International Journal of Economics and Finance, 11(3), 127-135. https://doi.org/10.5539/ijef.v11n3p127

18. Cherian, J., Umar, M., Thu, P. A., Nguyen-Trang, T., Sial, M. S., \& Khuong, N. V. (2019). Does Corporate Social Responsibility Affect the Financial Performance of the Manufacturing Sector? Evidence from an Emerging Economy. Sustainability, 11(4), 1182. https://doi.org/10.3390/su11041182

19. Cho, S. Y., Lee, C., \& Pfeiffer Jr, R. J. (2013). Corporate social responsibility performance and information asymmetry. Journal of Accounting and Public Policy, 32(1), 71-83. https://doi.org/10.1016/j.jacc pubpol.2012.10.005

20. Choongo, P. (2017). A longitudinal study of the impact of corporate social responsibility on firm performance in SMEs in Zambia. Sustainability, 9(8), 1300. https://doi.org/10.3390/su9081300

21. Cui, J., Jo, H., \& Na, H. (2018). Does corporate social responsibility affect information asymmetry? Journal of Business Ethics, 148(3), 549-572. https://doi.org/10.1007/s10551-015-3003-8

22. Davidson, R., \& MacKinnon, J. G. (2004). Econometric theory and methods (Vol. 5). Oxford University Press New York.

23. Dhaliwal, D. S., Li, O. Z., Tsang, A., \& Yang, Y. G. (2011). Voluntary nonfinancial disclosure and the cost of equity capital: The initiation of corporate social responsibility reporting. The Accounting Review, 86(1), 59-100. https://doi.org/10.2308/accr.00000005

24. Dhaliwal, D. S., Radhakrishnan, S., Tsang, A., \& Yang, Y. G. (2012). Nonfinancial disclosure and analyst forecast accuracy: International evidence on corporate social responsibility disclosure. The Accounting Review, 87(3), 723-759. https://doi.org/10.2308/accr-10218

25. Diamond, D. W. (1991). Monitoring and reputation: The choice between bank loans and directly placed debt. Journal of political economy, 99(4), 689-721. https://doi.org/10.1086/261775

26. Diamond, D. W., \& Verrecchia, R. E. (1991). Disclosure, liquidity, and the cost of capital. The journal of Finance, 46(4), 1325-1359. https://doi.org/10.1111/j.1540-6261.1991.tb04620.x

27. Donaldson, T., \& Preston, L. E. (1995). The stakeholder theory of the corporation: Concepts, evidence, and implications. Academy of management Review, 20(1), 65-91. https://doi.org/10.5465/amr.1995.9503271992

28. Drobetz, W., Grüninger, M. C., \& Hirschvogl, S. (2010). Information asymmetry and the value of cash. Journal of Banking \& Finance, 34(9), 2168-2184. https://doi.org/10.1016/j.jbankfin.2010.02.002

29. Easley, D., \& O'hara, M. J. T. j. o. f. (2004). Information and the cost of capital. 59(4), 1553-1583. https://doi.org/10.1111/j.1540-6261.2004.00672.x

30. Ehsan, S., \& Kaleem, A. (2012). An empirical investigation of the relationship between corporate social responsibility and financial performance: Evidence from manufacturing sector of Pakistan. Journal of Basic and Applied Scientific Research, 2(3), 2909-2922.

31. El Ghoul, S., Guedhami, O., Kwok, C. C., \& Mishra, D. R. (2011). Does corporate social responsibility affect the cost of capital? Journal of Banking \& Finance, 35(9), 2388-2406. https://doi.org/10.1016/j.jbankfi n.2011.02.007

32. Fieseler, C. (2011). On the corporate social responsibility perceptions of equity analysts. Business ethics: A European review, 20(2), 131-147. https://doi.org/10.1111/j.1467-8608.2011.01616.x 
33. Galbreath, J., \& Shum, P. (2012). Do customer satisfaction and reputation mediate the CSR-FP link? Evidence from Australia. Australian journal of management, 37(2), 211-229. https://doi.org/10.1177/0312896211432941

34. Gangi, F., Meles, A., Monferrà, S., \& Mustilli, M. (2018). Does corporate social responsibility help the survivorship of SMEs and large firms? Global Finance Journal, 100402. https://doi.org/10.1016/j.gfj.201 $\underline{8.01 .006}$

35. Garriga, E., \& Melé, D. (2004). Corporate social responsibility theories: Mapping the territory. Journal of Business Ethics, 53(1), 51-71. https://doi.org/10.1023/B:BUSI.0000039399.90587.34

36. Halov, N., \& Heider, F. (2011). Capital structure, risk and asymmetric information. The Quarterly Journal of Finance, 1(04), 767-809. https://doi.org/10.1142/S2010139211000171

37. Harjoto, M. A., \& Jo, H. (2011). Corporate governance and CSR nexus. Journal of Business Ethics, 100(1), 4567. https://doi.org/10.1007/s10551-011-0772-6

38. Harris, M., \& Raviv, A. (1991). The theory of capital structure. The journal of finance, 46(1), 297-355. https://doi.org/10.1111/j.1540-6261.1991.tb03753.x

39. Healy, P. M., \& Palepu, K. G. (2001). Information asymmetry, corporate disclosure, and the capital markets: A review of the empirical disclosure literature. Journal of Accounting and Economics, 31(1-3), 405-440. https://doi.org/10.2139/ssrn.258514

40. Ishtiaq, M., Latif, K., Khan, A. N., \& Noreen, R. (2017). Corporate Social Responsibility and Firm Performance: The Moderating Effect of Ownership Concentration. Journal of Managerial Sciences, 11(03), 354-386.

41. John, A., Qadeer, F., Shahzadi, G., \& Jia, F. (2019). Getting paid to be good: How and when employees respond to corporate social responsibility? Journal of cleaner production, 215, 784-795. https://doi.org/10.1 016/j.jclepro.2019.01.074

42. Khan, M. H., Fraz, A., \& Hasan, A. (2016). The Diversification Puzzle: The Role of Asymmetric Information and Insider Trading in Pakistan. The Lahore Journal of Economics, 21(2), 97-119. https://doi.org/10. 35536/lje.2016.v21.i2.a4

43. Kim, Y., Park, M. S., \& Wier, B. (2012). Is earnings quality associated with corporate social responsibility? The accounting review, 87(3), 761-796. https://doi.org/10.2308/accr-10209

44. Kiran, S., Kakakhel, S. J., \& Shaheen, F. (2015). Corporate social responsibility and firm profitability: A case of oil and gas sector of Pakistan. City University Research Journal, 5(1), 110-119.

45. Lang, L. H., Stulz, R., \& Walkling, R. A. (1991). A test of the free cash flow hypothesis: The case of bidder returns. Journal of financial economics, 29(2), 315-335. https://doi.org/10.2307/3666090

46. Lee, C.-H., Chen, R. C., Hung, S.-W., \& Yang, C.-X. (2020). Corporate social responsibility and firm value: The mediating role of investor recognition. Emerging Markets Finance and Trade, 56(5), 1043-1054. https://doi.org/10.1080/1540496x.2018.1501676

47. Lopatta, K., Buchholz, F., \& Kaspereit, T. (2016). Asymmetric information and corporate social responsibility. Business \& society, 55(3), 458-488. https://doi.org/10.1177/0007650315575488

48. Lu, C.-W., \& Chueh, T.-S. (2015). Corporate social responsibility and information asymmetry. Journal of applied finance and banking, 5(3), 105.

49. Martínez-Ferrero, J., Rodríguez-Ariza, L., García-Sánchez, I.-M., \& Cuadrado-Ballesteros, B. (2018). Corporate social responsibility disclosure and information asymmetry: the role of family ownership. Review of Managerial Science, 12(4), 885-916. https://doi.org/10.1007/s11846-017-0232-5

50. Mashayekhi, B., \& Bazaz, M. S. (2008). Corporate governance and firm performance in Iran. Journal of Contemporary Accounting \& Economics, 4(2), 156-172. https://doi.org/10.1016/S1815-5669(10)70033-3

51. Modigliani, F., \& Miller, M. H. (1963). Corporate income taxes and the cost of capital: a correction. The American economic review, 53(3), 433-443.

52. Nguyen, T., Pham, T., Le, Q., \& Bui, T. (2020). Impact of corporate social responsibility on organizational commitment through organizational trust and organizational identification. Management Science Letters, 10(14), 3453-3462. https://doi.org/10.5267/j.msl.2020.5.032

53. Nguyen, V. H., Agbola, F. W., \& Choi, B. (2019). Does corporate social responsibility reduce information asymmetry? Empirical evidence from Australia. Australian Journal of Management, 44(2), 188-211. https://doi.org/10.1177/0312896218797163

54. Piotroski, J. D., \& Roulstone, D. T. (2005). Do insider trades reflect both contrarian beliefs and superior knowledge about future cash flow realizations? Journal of Accounting and Economics, 39(1), 55-81. https://doi.org/10.1016/j.jacceco.2004.01.003

55. Pisani, N., Kourula, A., Kolk, A., \& Meijer, R. (2017). How global is international CSR research? Insights and recommendations from a systematic review. Journal of World Business, 52(5), 591-614. https://doi.org/10.1 016/j.jwb.2017.05.003

56. Pyo, G., \& Lee, H.-Y. (2013). The association between corporate social responsibility activities and earnings quality: Evidence from donations and voluntary issuance of CSR reports. Journal of Applied Business Research (JABR), 29(3), 945-962. https://doi.org/10.19030/jabr.v29i3.7793

57. Rettab, B., \& Mellahi, K. (2019). CSR and corporate performance with special reference to the Middle East. In Practising CSR in the Middle East (pp. 101-118). Springer. https://doi.org/10.1007/978-3-030-02044-6 6 
58. Saeidi, S. P., Sofian, S., Saeidi, P., Saeidi, S. P., \& Saaeidi, S. A. (2015). How does corporate social responsibility contribute to firm financial performance? The mediating role of competitive advantage, reputation, and customer satisfaction. Journal of business research, 68(2), 341-350. https://doi.org/10.1016/ j.jbusres.2014.06.024

59. Samet, M., \& Jarboui, A. (2017). How does corporate social responsibility contribute to investment efficiency? Journal of Multinational Financial Management, 40, 33-46. https://doi.org/10.1016/j.mulfin.2017.05.007

60. Saputri, L., \& Asrori, A. (2019). The Effect of Leverage, Liquidity and Profitability on Financial Distress with the Effectiveness of the Audit Committee as a Moderating Variable. Accounting Analysis Journal, 8(1), 38-44.

61. Sheikh, S. (2019). Corporate social responsibility and firm leverage: The impact of market competition. Research in International Business and Finance, 48, 496-510. https://doi.org/10.1016/j.ribaf.2018.11.002

62. Su, L., \& Swanson, S. R. (2019). Perceived corporate social responsibility's impact on the well-being and supportive green behaviors of hotel employees: The mediating role of the employee-corporate relationship. Tourism Management, 72, 437-450. https://doi.org/10.1016/j.tourman.2019.01.009

63. Sufi, A. (2007). Information asymmetry and financing arrangements: Evidence from syndicated loans. The journal of finance, 62(2), 629-668. https://doi.org/10.1111/j.1540-6261.2007.01219.x

64. Turban, D. B., \& Greening, D. W. (1997). Corporate social performance and organizational attractiveness to prospective employees. Academy of management journal, 40(3), 658-672. https://doi.org/10.5465/257057

65. Utama, D. P. (2019). The Effect of Corporate Social Responsibility and Firm Size Disclosure on Asymmetric Information in Companies Listed on Indonesia Stock Exchange. In 1st International Conference on Applied Economics and Social Science (pp. 339-344): Atlantis Press. https://doi.org/10.2991/icaess-19.2019.4

66. Utz, S. (2018). Over-investment or risk mitigation? Corporate social responsibility in Asia-Pacific, Europe, Japan, and the United States. Review of Financial Economics, 36(2), 167-193. https://doi.org/10.1 016/j.rfe.2017.10.001

67. Van Ha, N. (2018). Corporate social responsibility, Information asymmetry, Debt maturity and firm performance of Australian publicaly listed firms The University of Newcastle].

68. Wang, M.-L., Feng, Z.-Y., \& Huang, H.-W. (2013). Corporate social responsibility and cost of equity capital: a global perspective. Journal of Behavioral Finance, 9, 85-94

69. Yang, M., Bento, P., \& Akbar, A. (2019). Does CSR Influence firm performance indicators? evidence from Chinese pharmaceutical enterprises. Sustainability, 11(20), 5656. https://doi.org/10.3390/su11205656

70. Zhang, F., Li, M., \& Zhang, M. (2019). Chinese Financial Market Investors Attitudes toward Corporate Social Responsibility: Evidence from Mergers and Acquisitions. Sustainability, 11(9), 2615. https://doi.org/10.3 390/su11092615

71. Zhao, T., \& Xiao, X. (2019). The impact of corporate social responsibility on financial constraints: Does the life cycle stage of a firm matter? International Review of Economics \& Finance, 63, 76-93. https://doi.org/10.101 6/j.iref.2018.08.010 